\title{
Rola badań obciążeniowych w diagnostyce niedomykalności zastawki mitralnej
}

\author{
The use of exercise echocardiography in the evaluation of mitral regurgitation
}

\author{
Monika Budnik, Gabriela Parol \\ I Katedra i Klinika Kardiologii Warszawskiego Uniwersytetu Medycznego
}

\section{Streszczenie}

Niedomykalność zastawki mitralnej (MR) jest drugą pod względem częstości zastawkową wadą serca w Europie wymagającą leczenia chirurgicznego. Pierwotna (organiczna) postać wady obejmuje przypadki przebiegające z uszkodzeniem aparatu zastawkowego, zaś wtórna (czynnościowa) dotyczy przypadków, w których do MR dochodzi wtórnie do zaburzeń geometrii aparatu podzastawkowego wskutek poszerzenia i remodelingu lewej komory. Podstawowym badaniem diagnostycznym jest echokardiografia spoczynkowa, jednak ocena MR wyłącznie w badaniu spoczynkowym często może spowodować niedoszacowanie wady. Dlatego przydatne są badania obciążeniowe. Sam test wysiłkowy jest rzadko wykonywany u pacjentów z MR, natomiast echokardiografia wysiłkowa lub z obciążeniem farmakologicznym ma wartość prognostyczną, dostarcza dodatkowych informacji na temat istotności wady i ułatwia podejmowanie dalszych decyzji klinicznych.

Słowa kluczowe: niedomykalność zastawki mitralnej, test wysiłkowy, echokardiografia obciążeniowa

(Folia Cardiologica 2015; 10, 5: 380-385)

\section{Wstęp}

Niedomykalność mitralna (MR, mitral regurgitation) jest drugą pod względem częstości występowania wadą zastawkową wymagającą zabiegu chirurgicznego w Europie [1].

Wyróżnia się dwa typy MR - pierwotną i wtórną. Pierwotna (organiczna) MR obejmuje wszystkie przypadki z uszkodzeniem aparatu zastawkowego. Najczęściej występuje postać o etiologii zwyrodnieniowej, rzadziej przyczyną jest przebyta choroba reumatyczna lub infekcyjne zapalenie wsierdzia. Wtórna (czynnościowa) MR jest spowodowana zaburzeniem geometrii aparatu podzastawkowego wtórnego do poszerzenia i remodelingu lewej komory (LV, left ventricle). Jeżeli przyczyną wady jest choroba wieńcowa, to wtedy mówi się o niedokrwiennej MR. Kryteria rozpoznania ciężkiej MR według European Society Cardiology (ESC) przedstawiono w tabeli 1 [2]. Z kolei rycina 1 zawiera przy- kładowy wynik badania echokardiograficznego u pacjentki z dużą czynnościową MR.

\section{Test wysiłkowy}

Według wytycznych American College of Cardiology/American Heart Association (ACC/AHA) z 2014 roku [3] wykonanie testu wysiłkowego u pacjentów z wadą zastawkową serca może być uzasadnione (zalecenie w klasie Ila) u wybranych chorych z bezobjawową, ciężką postacią wady w trzech następujących przypadkach:

- by potwierdzić brak objawów podczas wysiłku;

- w celu oceny odpowiedzi hemodynamicznej na wysiłek;

- w celu ustalenia dalszej prognozy

U niektórych pacjentów test wysiłkowy może mieć dodatkową wartość służącą optymalizacji leczenia. U pacjentów z organiczną MR objawy zwykle pojawiają się pod-

Adres do korespondencji: lek. Monika Budnik, I Katedra i Klinika Kardiologii, Warszawski Uniwersytet Medyczny, ul. Banacha 1A, 02-097 Warszawa, e-mail: moni.budnik@gmail.com 
Tabela 1. Echokardiograficzne kryteria rozpoznania ciężkiej niedomykalności zastawki mitralnej (na podstawie [2])

\begin{tabular}{|c|c|c|}
\hline Metody & \multicolumn{2}{|l|}{ Opis } \\
\hline \multicolumn{3}{|l|}{ Metody jakościowe } \\
\hline Morfologia zastawki & \multicolumn{2}{|c|}{ Wiotki płatek/zerwany mięsień brodawkowaty/duży defekt koaptacji } \\
\hline Fala zwrotna niedomykalności & \multicolumn{2}{|c|}{$\begin{array}{l}\text { Bardzo duży strumień centralny fali zwrotnej lub ekscentryczny strumień wywołujący zawirowa- } \\
\text { nia i osiągający ścianę tylną lewego przedsionka }\end{array}$} \\
\hline Wysycenie spektrum CW & \multicolumn{2}{|l|}{ Gęste/trójkątne } \\
\hline Inne & \multicolumn{2}{|c|}{ Duża strefa konwergencji } \\
\hline \multicolumn{3}{|l|}{ Metody półilościowe } \\
\hline Szerokość talii fali zwrotnej [mm] & \multicolumn{2}{|c|}{$\geq 7$ (> 8 głowicą dwupłaszczyznową) } \\
\hline Wsteczny przepływ żylny & \multicolumn{2}{|c|}{ Skurczowe odwrócenie przepływu w żyłach płucnych } \\
\hline Napływ [m/s] & \multicolumn{2}{|c|}{ Napływ mitralny $z$ dominującą falą $E \geq 1,5$} \\
\hline Inne & \multicolumn{2}{|c|}{ TVI mitralne/TVI aortalne $>1,4$} \\
\hline \multicolumn{3}{|l|}{ Metody ilościowe } \\
\hline $\mathrm{EROA}\left[\mathrm{mm}^{2}\right]$ & Organiczna $\geq 40$ & Czynnościowa $\geq 20$ \\
\hline RVol (ml/cykl) & Organiczna $\geq 60$ & Czynnościowa $\geq 30$ \\
\hline Powiększenie jam serca & Organiczna LV, LA & \\
\hline
\end{tabular}

CW (continuous wave) - fala ciągła; TVI (time-velocity integral) - całka czas-prędkość; EROA (effective regurgitant orifice area) - efektywne pole ujścia fali zwrotnej; RVol (regurgitant volume) - objętość fali zwrotnej; LV (left ventricle) - lewa komora; LA (left atrial) - lewy przedsionek

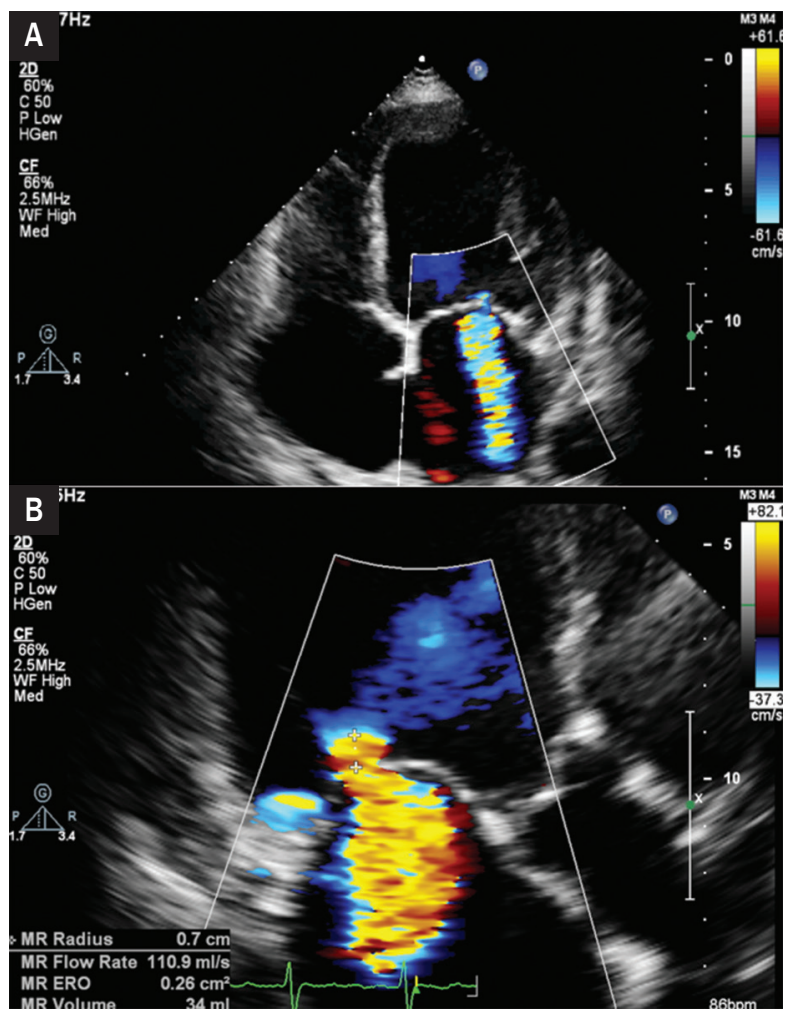

Rycina 1A, B. Duża niedokrwienna niedomykalność zastawki mitralnej (materiał I Katedry i Kliniki Kardiologii Warszawskiego Uniwersytetu Medycznego)

czas wysiłku. W tej grupie chorych są tacy, u których spoczynkowy obraz wady nie koreluje z objawami. Jest to związane z powolną progresją zmian. Część pacjentów może źle rozpoznawać objawy lub je negować, ponieważ podświadomie zmieniają styl życia, ograniczając aktywność. U tych pacjentów w ustaleniu charakteru objawów mogą pomóc zmiany hemodynamiczne wywołane wysiłkiem. Test wysiłkowy pozwala ocenić rzeczywistą tolerancję wysiłku, a jego wynik może stanowić punkt odniesienia dla oceny symptomów w przyszłości. Dodatkową informację odnośnie sercowych i pozasercowych przyczyn ograniczenia tolerancji wysiłku u pacjentów z MR może wnieść ocena pochłaniania tlenu w badaniu spiroergometrycznym (CPET, cardiopulmonary exercise testing) [4]. Jednak klasyczny test wysiłkowy bez obrazowania jest rzadko wykonywany u pacjentów z MR. Większą wartość prognostyczną ma w tym przypadku echokardiografia obciążeniowa.

\section{Echokardiografia obciążeniowa}

Niezależnie od stopnia MR w badaniu echokardiograficznym można zaobserwować zmniejszenie istotności wady w spoczynku i znaczny wzrost lub brak zmiany w trakcie wysiłku. Ocena MR tylko w spoczynku może spowodować niedoszacowanie wady wraz ze wszystkimi konsekwencjami klinicznymi. Z tego powodu użytecznym badaniem jest echokardiografia obciążeniowa, która pozwala uzyskać dodatkowe informacje dotyczące istotności MR i ułatwia podejmowanie dalszych decyzji klinicznych. Istnieją dwie metody echokardiograficznego badania obciążeniowego - z zastosowaniem dobutaminy lub próba wysiłkowa wykonywana na bieżni lub ergometrze rowerowym. 


\section{Badanie z obciążeniem farmakologicznym}

Dobutamina zmniejsza obciążenie wstępne i następcze oraz poprawia kurczliwość. Zmiany hemodynamiczne wywołane dobutaminą mogą w rzeczywistości prowadzić do ograniczenia stopnia nasilenia przewlekłej niedokrwiennej MR, z jednym wyjątkiem - pacjentów, u których wyindukowano niedokrwienie ściany tylno-bocznej LV. U tych pacjentów stopień nasilenia MR może się nasilić w czasie próby dobutaminowej z powodu przejściowego niedokrwienia tyIno-bocznej ściany, co spowoduje rozwój „prawdziwej” niedokrwiennej MR [5]. U takich chorych rewaskularyzacja wieńcowa tętnicy odpowiedzialnej za niedokrwienie mięśnia sercowego i niedokrwienną MR doprowadzi do zmniejszenia stopnia nasilenia MR, znacząco poprawiając rokowanie. Innym ważnym zastosowaniem echokardiograficznej próby dobutaminowej w ocenie niedokrwiennej MR jest wykrywanie żywotnego mięśnia sercowego, co może prowadzić do zmniejszenia stopnia MR podczas badania z zastosowaniem małej dawki dobutaminy.

\section{Echokardiograficzna próba wysiłkowa}

Bardziej fizjologiczną metodą oceny MR jest echokardiografia obciążeniowa na przeznaczonym do tego ergometrze rowerowym, który umożliwia stałe monitorowanie echokardiograficzne w czasie wysiłku. Echokardiograficzna próba wysiłkowa ma kilka zalet. Po pierwsze, wykorzystuje się wysiłek fizjologiczny. Po drugie, pozwala na ciągłe monitorowanie wszystkich mechanizmów biorących udział w patogenezie niedokrwiennej niewydolności serca, tj. zmian w geometrii zastawki mitralnej podczas wysiłku i zmian w kurczliwości LV, wykrywa dyssynchronię LV, a co najważniejsze pozwala na dokładną i powtarzalną ocenę efektywnego pola ujścia fali zwrotnej (EROA, effective regurgitant orifice area). Po trzecie, umożliwia ocenę następstw niedokrwiennej MR poprzez oszacowanie wartości skurczowego ciśnienia w tętnicy płucnej (SPAP, systolic pulmonary artery pressure) w czasie wysiłku. Po czwarte, nasilenie niedokrwiennej MR podczas wysiłku można skorelować z objawami zgłaszanymi przez pacjenta [5]. Wysiłkowa duszność związana jest z nasileniem MR i wzrostem SPAP [6]. Znaczne, indukowane wysiłkiem zwiększenie EROA, do wartości większej lub równej $13 \mathrm{~mm}^{2}$, wiąże się ze wzrostem śmiertelności i częstości hospitalizacji z powodu zaostrzenia niewydolności serca i poważnych zdarzeń sercowych [7].

Echokardiograficzną próbę wysiłkową można przeprowadzić na bieżni ruchomej lub na ergometrze rowerowym. Ciagłe badanie echokardiograficzne $w$ trakcie wysiłku nie jest możliwe podczas badania na bieżni, dlatego próbę najczęściej wykonuje się tuż po zakończeniu wysiłku. Niezwykle ważne jest, aby badanie wykonać jak najszybciej $(\leq 1 \mathrm{~min}$ po zakończenia wysiłku). By to było możliwe, pacjent natychmiast po zakończeniu wysiłku jest proszony o położenie się na leżance na lewym boku. Badanie przeprowadza się zgodnie z metodyką stosowaną w elektrokardiograficznych próbach wysiłkowych, najczęściej według zmodyfikowanego protokołu Bruce'a. Badanie na ergometrze rowerowym (zwłaszcza leżącym) umożliwia stałe monitorowanie echokardiograficzne. Pacjent pedałuje z coraz większym obciążeniem przy stałej liczbie obrotów na minutę. Obciążenie początkowe wynosi $25 \mathrm{~W}$, następnie jest stopniowo zwiększane o 25W co 2-3 minuty przy jednoczesnym obrazowaniu echokardiograficznym [8].

Według standardów Europejskiego Towarzystwa Echokardiograficznego (European Society of Echocardiography) warunkiem uznania próby wysiłkowej za diagnostyczna jest:

- osiągnięcie maksymalnego obciążenia;

- osiągnięcie limitu tętna;

- wystąpienie bólu w klatce piersiowej;

- pogorszenie kurczliwości co najmniej dwóch segmentów LV;

- spełnienie kryteriów testu dodatniego elektrokardiograficznie.

Niediagnostyczne badanie to przerwanie testu z powodu:

- wzrostu ciśnienia skurczowego powyżej 220 mm Hg lub rozkurczowego ponad $120 \mathrm{~mm} \mathrm{Hg}$;

- objawowego spadku ciśnienia skurczowego o więcej niż $40 \mathrm{~mm} \mathrm{Hg;}$

- wystąpienia istotnej arytmii komorowej lub nadkomorowej;

- pojawienie się uciążliwych dla pacjenta działań niepożądanych.

Podczas echokardiograficznego testu wysiłkowego należy odpowiedzieć na pytania:

- co się dzieje z MR podczas wysiłku - zmniejsza się, zwiększa czy pozostaje na jednakowym poziomie;

- czy dochodzi do zwiększenia "związania” (tethering) płatków zastawki;

- czy pojawiły się nowe zaburzenia kurczliwości;

- czy występuje istotna dysfunkcja rozkurczowa LV w czasie wysiłku;

- czy dochodzi do patologicznego wzrostu SPAP w trakcie wysiłku;

- jaki jest mechanizm zmiany nasilenia MR [5].

\section{Bezpieczeństwo badania}

Bezpieczeństwo echokardiogarficznej próby wysiłkowej udowodniono na podstawie wieloletnich doświadczeń w wykonywaniu badania. Na podstawie rejestrów wiadomo, że badanie wysiłkowe jest bezpieczniejsze niż zastosowanie farmakologicznego obciążenia [9]. Według AHA, na podstawie ponad 1000 badań z udziałem milionów pacjentów, zgony zdarzają się w jednym przypadku na 10000 badań [10]. Poważne zdarzenia niepożądane, takie jak zawał serca, migotanie komór, utrwalony częstoskurcz komorowy czy udar mózgu, występują u jednego na 6000 pacjentów [9]. Echokardiograficzna próba wysiłkowa jest bezpieczna nawet u pacjentów, którzy kilka dni wcześniej przebyli epizod 


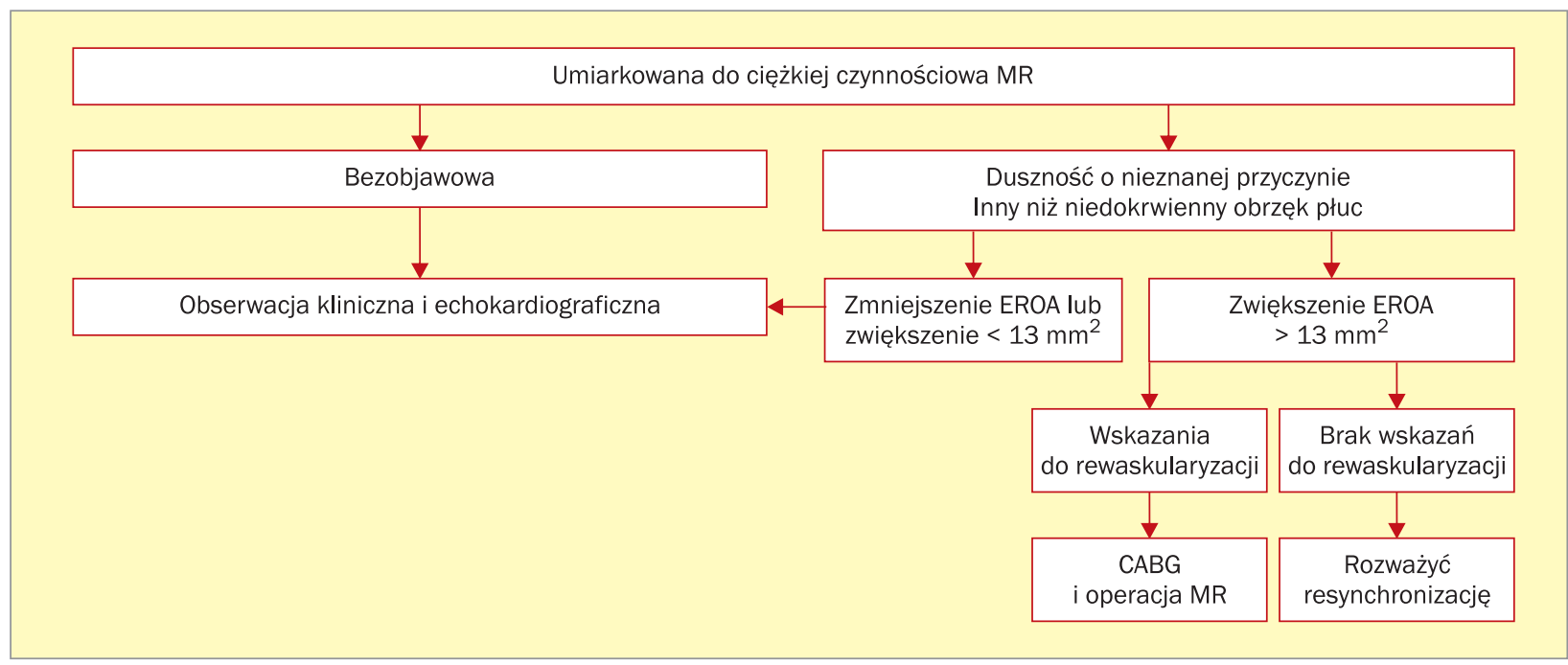

Rycina 2. Algorytm zastosowania echokardiograficznej próby wysiłkowej (na podstawie [10]); MR (mitral regurgitation) - niedomykalność mitralna; EROA (effective regurgitant orifice area) - efektywne pole ujścia fali zwrotnej; CABG (coronary artery bypass grafting) - pomostowanie aortalno-wieńcowe

obrzęku płuc, z zastrzeżeniem, że są w klasie niższej niż IV według New York Heart Association (NYHA) i pozostają w stabilnym stanie [11].

\section{Przeciwwskazania}

Przeciwwskazaniem do echokardiograficznego testu wysiłkowego są niestabilność hemodynamiczna, poważne, niekontrolowane nadciśnienie tętnicze oraz zła jakość obrazowania w badaniu spoczynkowym [8]. Pozostałe przeciwwskazania są takie jak w elektrokardiograficznej próbie wysiłkowej i obejmują: ostry zawał serca (w ciągu 2 dni), niestabilną chorobę wieńcową, źle kontrolowane zaburzenia rytmu serca powodujące objawy kliniczne, objawową ciężką stenozę aortalną, zdekompensowaną niewydolność serca, aktywne infekcyjne zapalenie wsierdzia, zapalenie mięśnia sercowego lub zapalenie osierdzia, ostre rozwarstwienie aorty, zatorowość płucną lub obwodową.

Algorytm zastosowania echokardiograficznej próby wysiłkowej przedstawiono na rycinie 2.

\section{Wskazania zależnie od etiologii}

W rekomendacjach ESC i AHA wyróżniono wskazania do wykonania echokardiografii obciążeniowej w zależności od etiologii MR [8, 12].

\section{Organiczna niedomykalność mitralna}

U niewykazujących objawów pacjentów z więcej niż umiarkowaną pierwotną MR echokardiografia obciążeniowa może ujawnić dynamiczną MR w około 1/3 przypadków. U 32-66\% pacjentów z umiarkowaną MR może się rozwi- nąć duża niedomykalność podczas wysiłku [13]. Zjawisko to jest często związane z indukowanym wysiłkiem nadciśnieniem płucnym (PH, pulmonary hypertension) [14]. Zarówno dynamiczna MR, jak i indukowane wysiłkiem PH może być zwiastunem wystąpienia objawów klinicznych w krótkotrwałej obserwacji. W zaleceniach ESC wskazuje się, że indukowane wysiłkiem PH stanowi wskazanie klasy Ilb do wymiany zastawki mitralnej u niewykazujących objawów pacjentów bez dysfunkcji/rozstrzeni LV [1]. Pacjenci z wysiłkowym zwiększeniem stopnia MR i indukowanym wysiłkiem PH mogą odnieść korzyść z wczesnej operacji zastawki mitralnej. Ponieważ brak rezerwy kurczliwości LV jest niezależnym czynnikiem złego rokowania, to leczenie operacyjne powinno być rozważane u pacjentów bez objawów z ciężką MR. W przypadku leczenia farmakologicznego takich chorych należy ściśle monitorować (np. co 3-6 miesięcy). Natomiast niewykazujący objawów pacjenci bez indukowanego wysiłkiem PH i z zachowana rezerwą kurczliwości powinni być monitorowani raz w roku [15].

W codziennej praktyce obciążeniowa echokardiografia doplerowska jest użyteczną metodą u pacjentów bez objawów z umiarkowaną do ciężkiej pierwotną MR z zachowaną frakcją wyrzutową (EF, ejection fraction) w celu stratyfikacji ryzyka i określenia czasu, w którym będzie konieczne leczenie operacyjne, zwłaszcza w przypadku chorych, u których stosunek ryzyka do korzyści z interwencji chirurgicznej jest niepewny [15].

U niewykazujących objawów pacjentów z ciężką MR echokardiografia obciążeniowa umożliwia identyfikację osób z nierozpoznanymi objawami lub utajoną dysfunkcją LV. Może być również przydatna u chorych z dysproporcją między objawami klinicznymi a stopniem MR w badaniu spoczynkowym. Nasilenie stopnia MR, zwiększenie PH, 
upośledzona wydolność fizyczna, wystąpienie objawów w czasie wysiłku mogą być użyteczne w zidentyfikowaniu pacjentów obciążonych wysokim ryzykiem, którzy odniosą korzyść z leczenia operacyjnego [8]. Wzrost PH do wartości ponad $60 \mathrm{~mm}$ Hg w trakcie wysiłku stanowi punkt odcięcia dla wymiany zastawki mitralnej w przypadku pacjentów bez objawów z ciężką MR. Brak przyrostu EF (<4\%), zmniejszenie objętości końcowoskurczowej (ESV, end systolic volume) po wysiłku świadczą o upośledzeniu rezerwy kurczliwości, co się wiąże ze śmiertelnością pooperacyjną. Niewielka zmiana globalnego odkształcenia podłużnego (<1,9\%) koreluje z pooperacyjną dysfunkcją LV [16].

\section{Czynnościowa niedomykalność mitralna}

Czynnościowa MR, jeżeli występuje, to może mieć różne nasilenie i powodować gorsze rokowanie [17, 18]. Dynamiczna MR jest związana z indukowanymi wysiłkiem zmianami konfiguracji zastawki oraz zaburzoną synchronią LV. Istotna MR jest bardziej prawdopodobna u pacjentów z dusznością ograniczającą wysiłek oraz u chorych hospitalizowanych z powodu obrzęku płuc. Wystąpienie ostrej MR podczas wysiłku stanowi predyktor zgonu sercowego i hospitalizacji z powodu niewydolności serca [11]. U pacjentów z umiarkowaną MR, u których występuje duszność wtórnie do nasilenia stopnia MR i PH, należy rozważyć operację naprawczą zastawki mitralnej podczas operacji pomostowania aortalno-wieńcowego [2].

Badanie wysiłkowe może być pożyteczne u pacjentów:

- z dusznością wysiłkową nieproporcjonalną do stopnia dysfunkcji LV i stopnia MR;

- z epizodami ostrego obrzęku płuc bez znanej przyczyny;

- z umiarkowaną MR przed operacyjną rewaskularyzacją. Ilościowa ocena czynnościowej niedomykalności jest możliwa poprzez zastosowanie metody proksymalnych stref konwergencji (PISA, proximal isovelocity surface area method). Mogą wystąpić dwa typy odpowiedzi na wysiłek fizyczny:
- u chorych z ograniczoną rezerwą kurczliwości dojdzie do zmniejszenia objętości wyrzutowej (SV, systolic volume), zwiększenia EROA i nasilenia duszności w czasie spoczynku;

- u chorych z zachowaną rezerwą kurczliwości wysiłek zwiększy SV, a EROA nie ulegnie zmianie lub nawet się zmniejszy [19].

Znaczne, wywołane wysiłkiem, zwiększenie EROA $\left(\geq 13 \mathrm{~mm}^{2}\right)$ wiąże się z dusznością i wystąpieniem obrzęku płuc $[11,20]$. Dynamiczna MR jest również predyktorem śmiertelności i hospitalizacji z powodu niewydolności serca. Echokardiografia obciążeniowa może ujawnić hemodynamicznie istotną MR u pacjentów z czynnościową niedokrwienną dysfunkcją skurczową LV i jedynie małą lub umiarkowaną MR w spoczynku i w ten sposób umożliwić identyfikację chorych z grupy wysokiego ryzyka niewydolności serca i zgonu.

\section{Podsumowanie}

W grupie pacjentów z MR badania obciążeniowe mają dużą wartość diagnostyczną i prognostyczną. Sam test wysiłkowy jest badaniem rzadko wykonywanym, głównie w celu oceny tolerancji wysiłku u pacjentów z umiarkowaną lub ciężką organiczną MR. Szerzej wykorzystuje się echokardiografię obciążeniową z zastosowaniem dobutaminy lub wysiłku. Badanie to dostarcza dodatkowych informacji na temat istotności MR i ułatwia podejmowanie dalszych decyzji klinicznych. W przypadku pacjentów bez objawów z ciężką MR echokardiografia obciążeniowa umożliwia identyfikację osób z nierozpoznanymi objawami lub utajoną dysfunkcją LV i jest użyteczną metodą stratyfikacji ryzyka i określenia czasu leczenia operacyjnego.

\section{Konflikt interesów}

Autorki deklarują brak konfliktu interesów.

\section{Abstract}

Mitral regurgitation (MR) is the second most common valvular disease in Europe that requires surgical intervention. Primary (organic) MR covers all cases that affect lesions of valve apparatus, and secondary (functional) MR results from geometrical distortion of the subvalvular apparatus, secondary to left ventricle enlargement and remodelling. The key diagnostic investigation is resting echocardiography, but assessment of MR only at rest may underestimate the grade of valvular disease. Thus stress examinations are recommended. Sole exercise testing is rarely performed in patients with MR, but stress echocardiography (under exercise or pharmacological stress) is of a prognostic value, provides additional information concerning the severity of MR and enables making further clinical decisions.

Key words: mitral regurgitation, exercise testing, stress echocardiography

(Folia Cardiologica 2015; 10, 5: 380-385) 


\section{Piśmiennictwo}

1. lung B., Baron G., Butchart E.G. i wsp. A prospective survey of patients with valvular heart disease in Europe: the Euro Heart Survey on Valvular Heart Disease. Eur. Heart J. 2003; 24: 1231-1243.

2. The Joint Task Force on the Management of Valvular Heart Disease of the European Society of Cardiology (ESC) and the European Association for Cardio-Thoracic Surgery (EACTS). Guidelines on the management of valvular heart disease (version 2012). Eur. Heart J. 2012; 33: 2451-2496.

3. Nishimura R., Otto C., Bonow R. i wsp. 2014 AHA/ACC guideline for the management of patients with valvular heart disease. Circulation 2014; 129: e521-e643.

4. Messika-Zeitoun D., Johnson B.D., Nkomo V. i wsp. Cardiopulmonary Exercise Testing Determination of functional Capacity in Mitral Regurgitation. JACC 2006; 47: 2521-2527.

5. Dulgheru R., Magne J., Lancellotti P., Pierard L. Dynamic ischaemic mitral regurgitation and the role of stress echocardiography. J. Cardiovasc. Echography 2013; 23: 10-17.

6. Pierard L.A., Lancellotti P. The role of ischemic mitral regurgitation in the pathogenesis of acute pulmonary edema. N. Engl. J. Med. 2004; 351: 1627-1634.

7. Lancellotti P., Gerard P.L., Pierard L.A. Long-term outcome of patients with heart failure and dynamic functional mitral regurgitation. Eur. Heart J. 2005; 26: 1528-1532.

8. Sicari R., Nihoyannopolous P., Evangelista A. i wsp. Stress echocardiography expert consensus statement. Eur. J. Echocardiogr. 2008; 9: 415-437.

9. Varga A., Garcia M.A., Picano E. Safety of stress echocardiography (from the International Stress Echo Complication Registry). Am. J. Cardiol. 2006; 98: 541-543.

10. Fletcher G.F., Balady G.J., Amsterdam E.A. i wsp. Exercise standards for testing and training: a statement for healthcare professionals from the American Heart Association. Circulation 2001; 104: 1694-1740.
11. Pierard L.A., Lancelotti P. The role of ischemic mitral regurgitation in the pathogenesis of acute pulmonary edema. N. Engl. J. Med. 2004; 35: 1627-1634.

12. Pellikka P., Nagueh S., Elhendy A. i wsp.; American Society of Echocardiography. American Society of Echocardiography recommendations for performance, interpretation, and application of stress echocardiography. J. Am. Soc. Echocardiogr. 2007; 20: 1021-1041.

13. Magne J., Lancellotti P., Piérard L.A. Exercise-induced changes in degenerative mitral regurgitation. J. Am. Coll. Cardiol. 2010; 56: 300-309.

14. Lee R., Haluska B., Leung D.Y. i wsp. Functional and prognostic implications of left ventricular contractile reserve in patients with asymptomatic severe mitral regurgitation. Heart 2005; 91: 1407-1412.

15. Lancellotti P., Magne J. Stress echocardiography in regurgitant valve disease. Circ. Cardiovasc. Imaging 2013; 6: 840-849.

16. Lancellotti P., Cosyns B., Zacharakis D. i wsp. Importance of left ventricular function and functional reserve in patients with degenerative mitral regurgitation: assessment by 2-D speckle tracking. J. Am. Soc. Echocardiogr. 2008; 21: 1331-1336.

17. Grigioni F., Enriquez-Sarano M., Zehr K.J. i wsp. Ischemic mitral regurgitation: long-term outcome and prognostic implications with quantitative Doppler assessment. Circulation 2001; 103: 1759-1764.

18. Grigioni F., Detaint D., Avierinos J.F. i wsp. Contribution of ischemic mitral regurgitation to congestive heart failure after myocardial infarction. J. Am. Coll. Cardiol. 2005; 45: 260-267.

19. Płońska-Gościnak E., Gackowski A., Gąsior Z. i wsp. Recommendations of the Echocardiography Working Group of the Polish Cardiac Society for stress echocardiography use in clinical practice 2011. Kardiol. Pol. 2011; 69: 642-648.

20. Lancelotti P., Gerard P., Pierard L.A. Long-term outcome of patients with heart failure and dynamic functional mitral regurgitation. Eur. Heart J. 2005; 26: 1528-1532. 